\title{
Civilisations
}

Revue internationale d'anthropologie et de sciences

humaines

40-1 | 1991

L'Asie et le Pacifique

\section{The Years of Reform in China: Economic Growth Versus Modernization}

\section{I-Chuan Wu-Beyens}

\section{OpenEdition \\ Journals}

Electronic version

URL: http://journals.openedition.org/civilisations/1680

DOI: $10.4000 /$ civilisations. 1680

ISSN: 2032-0442

\section{Publisher}

Institut de sociologie de l'Université Libre de Bruxelles

\section{Printed version}

Date of publication: 1 January 1992

Number of pages: 101-132

ISBN: 2-87263-063-5

ISSN: 0009-8140

\section{Electronic reference}

I-Chuan Wu-Beyens, "The Years of Reform in China: Economic Growth Versus Modernization », Civilisations [Online], 40-1 | 1991, Online since 07 July 2009, connection on 19 April 2019. URL : http:// journals.openedition.org/civilisations/1680 ; DOI : 10.4000/civilisations.1680 


\title{
THE YEARS OF REFORM IN CHINA : ECONOMIC GROWTH VERSUS MODERNIZATION
}

\author{
I-Chuan WU-BEYENS
}

In December 1978, after a period of intense power struggle and following a discussion among the top leaders, the Chinese Communist Party announced solemnly that the focus of its work will no longer be class struggle but should be replaced by economic development. Thus started the reforms which have made China socio-economically fundamentally different in many ways from the day Chairman Mao Zedong died. However, the political essence of the regime appears to be hard to modify.

The economic reform has brought about significant improvements in the level of living standards of most Chinese and impressive economic growth rates have been registered. The table shows the comparison of some of the economic indexes before and after the reform. The "success" of China's economic reform has received much praises. However, we think that the outcome of these ten years of important changes can best be qualified as "economic growth" rather than "development". Furthermore, it is our opinion that in many ways the goal of "modernization" is even more difficult to be attained after this ten years of unbalanced and lopsided growth. Behind the flourishing facade of Chinese society lies a multitude of problems. In analysing these problems it is hoped that the remarkable events which started to unfold in April 1989 , as well as the enourmous stakes involved in the outcome of China's future political development could be better understood. 
Table

\section{COMPARISON OF ECONOMIC INDEXES BEFORE AND AFTER REFORM OF 1978}

(1952-78)

\begin{tabular}{|c|c|c|c|}
\hline & 1952 & 1978 & $\begin{array}{l}\text { Annual rate } \\
\text { of growth }\end{array}$ \\
\hline 1. National income (NDMP) billion yuan ${ }^{(a)}$ & 58.9 & 301 & 6.5 \\
\hline $\begin{array}{l}\text { 2. Total value of industry production-billion } \\
\text { yuan (a) }\end{array}$ & 34.9 & 406.7 & 9.9 \\
\hline 3. Heavy industry production-billion yuan (a) & 12.4 & 231.4 & 11.9 \\
\hline 4. Light industry production-billion yuan $(\mathrm{a})$ & 22.5 & 173.3 & 8.2 \\
\hline $\begin{array}{l}\text { 5. Total value of agricultural production- } \\
\text { billion yuan }(a)\end{array}$ & 46.1 & 156.7 & 4.8 \\
\hline $\begin{array}{l}\text { 6. Total value of agricultural output billion } \\
\text { yuan (b) }\end{array}$ & 46.1 & 128.9 & 4.0 \\
\hline $\begin{array}{l}\text { 7. Amount of food grain productin-unprocessed } \\
\text { million tons }\end{array}$ & 163.9 & 304.8 & 2.4 \\
\hline 8. Population-yearly average million persons $(c)$ & 574.8 & 962.6 & 2.0 \\
\hline 9. Per capita food grain output-unprocessed, kg & 285.1 & 316.6 & 0.4 \\
\hline 10.Per capita national income (yuan) ${ }^{(a)}$ & 104 & 315 & 4.4 \\
\hline
\end{tabular}

\section{Sources:}

1952, 1978 and 1984 from State Statistical Bureau, State Council of People's Republic of China, ed. Zhongsuo Tongij Nianjian, 1985, (Statiscal Yearbook People's Republic of China), (Beijing : Zhongguo Tongji chubanshe, October 1985).

1988 : "Communique on fulfilment of China's 1988 National Economic Plan", Beijing Review no. 10 (March 6-12, 1989). 
Table

\section{COMPARISON OF ECONOMIC INDEXES BEFORE AND AFTER REFORM OF 1978}

\begin{tabular}{|c|c|c|c|c|c|}
\hline \multicolumn{3}{|c|}{$(1978-84)$} & \multicolumn{3}{|l|}{$(1984-88)$} \\
\hline & \multirow[t]{2}{*}{$\begin{array}{l}\text { Annual rate } \\
\text { of growth }\end{array}$} & \multirow[b]{2}{*}{1988} & \multirow[t]{2}{*}{$\begin{array}{l}\text { Annual rate } \\
\text { of growth }\end{array}$} & \multicolumn{2}{|c|}{$\begin{array}{l}\text { Annual rate } \\
\text { of growth }\end{array}$} \\
\hline 1984 & & & & $1978-89^{\circ}$ & $1952-88$ \\
\hline $\begin{array}{l}564.3 \\
704.2\end{array}$ & $\begin{array}{r}11 \\
9.6\end{array}$ & $\begin{array}{r}1.153 .3 \\
1.810\end{array}$ & $\begin{array}{l}19.6 \\
26.6\end{array}$ & $\begin{array}{l}14.4 \\
16.1\end{array}$ & $\begin{array}{r}8.6 \\
11.6\end{array}$ \\
\hline 370.7 & 8.2 & 915 & 23.3 & 14.7 & 12.7 \\
\hline 333.5 & 11.3 & 895 & 28.0 & 17.7 & 10.8 \\
\hline 375.5 & 15.7 & 561.8 & 35.3 & 13.6 & 7.2 \\
\hline 280.1 & 13.8 & 261.2 & -1.6 & 7.3 & 4.9 \\
\hline 407.3 & 5 & 394.0 & -0.8 & 2.6 & 2.5 \\
\hline & 1.2 & 1.096 .1 & 1.45 & 1.3 & 1.8 \\
\hline 393.6 & 3.7 & 359.5 & -21 & 1.3 & 0.6 \\
\hline $\begin{array}{r}548 \\
548\end{array}$ & 9.7 & 1.052 & 7.7 & 12.8 & 6.6 \\
\hline
\end{tabular}

Notes : Annual rate of growth is derived as a compound annual rate of growth betwees the years at both ends of the phase indicated.

Remark : like most developing countries the quality of China's statistics present various reliability, the biggest problem is that of the population total where serious under-registration of births, especially in the last ten years is known. However, this figures show the general trend of development and are basically the same set of statistics used by the Chinese government in planning.

Per capita figure is derived from the yearly population average and the national figure. (a) Price of that year

(b) = Total value of agricultural production - total value of non-agricultural production (c) The figures include the population and army men in the service of the 29 provinces municipalities and autonomous regions on the mainland, but not those of Taiwan Province. 
This article is divided into four parts. We start with the discussion of the evolution of the economic reform. It shows that the adaptation of the popular 'responsibility system' and its application in the urban areas and industrial sector had changed the nature of the 'reform' into a formidable movement of seeking 'economic gains' in every level of the society, and that the peasants who had benefitted from the first stage of the reform turned quickly into victims of the system. In the second part we analyse more specifically problems arisen form these changes, other than various socio-economic issues, the most important ills coming from the confusion between official and private activities.

The section of inherent limitation of reform shows that the mistakes were not accidental. The non-systematic approach towards the reform finds its origin in the voluntaristic nature which marks China's Communist Party all through its history, and shows also that the political implications which hindered the progress of the reform and much resented by the people are the results of the party's determination to hold on to absolute power. Economic retrenchment is the logical outcome of such an attitude. In the concluding section we point out the major problematic outcomes of the reform which furthered China from her pronounced goal of 'modernizing' herself. but we also point out that some hope exists for the future.

\section{Stages of Reform}

Although the reforms have been desired by the new leadership after 1978, much of the direction of its development has not been intended or planned by the government. A brief account of the stages of its development would shed light on the basic ideas, the compromises and obstacles, and the outcome of these ten years of reform. 
One of the major decisions taken in the end of 1978 was to release the pent up productivity by giving more initiatives to enterprises and individuals through relaxing the central planning. Much of the economic powers have been given to local government and, in the same spirit, a major reajustment of rural distribution and management has been called for. The reform of the agricultural sector has been singled out from the outset. The procurement prices of agricultural products had been raised after decades of stagnation ${ }^{1}$, and the pre-Cultural Revolutionary "liberties" of private plot, free market and familly sidelines have been reencouraged. Under this new political atmosphere, the "household responsibility" system which has already existed in some areas well before 1979 have been quickly adopted all over the countryside.

Finally sanctioned offically by the Document No. 1 of the central committee of the Communist Party, in 1983, the responsibility system reinstated households as the basic autonomous economic units. Rural households have total organizational and management power over the land they till and over their labour force deployment. They have to sell a quota of the agricultural products at a reasonable level and a large fraction at above quota price to the State via the rural collectives. With the different working organization and management plus the raise of governmental purchasing prices, agricultural productivities increased very rapidly. The annual growth rate of total value of agricultural production of 1978-1984 was more than three times higher than between 1952 and 1978. See Table. A wide range of diversified culture has replaced the drive for grain production of the last twenty years ${ }^{2}$. Numerous rural enterprises have been set up with surplus funds and redundant labour force. Various service trades flourished and commerce can no longer be contained within rural markets. 
The moving situations obliged the government to legalize a large number of practices, such as allowing people to be detached from economic activities organized by the rural collectives, formation of specialized farm or non-farm households, employment of workers or apprentices, conducting inter administrative areas trades, and the organization of joint economic activities out of the collective framework. The shape of rural reform has largely been created from the "bottom up" rather than from the "top down". Most of the time the governmental function has been limited to legitimating practices which have proven profitable. Policies such as the formal obliteration of the People's Commune between 1982 and 1984, the extremely effective political control organ of the Party, turn out to be the exact contrary of the original intention which was to reinforce the rural collectives.

1984 marked a turning point in Chinese economic reform. The part of economy under central "planning" was further reduced and the reform of the industrial and urban sectors after the rural "responsibility" model was pressed forward. One of the important factor in this decision is the bumper harvest of most of the major farm crops in 1984. After three years of high growth, the total grain output bypassed the mark of 400 million tons for the first time. The government found it more and more difficult financially to meet the obligation of purchasing, at the same time the problems of storage, processing and transportation have become more and more acute. In order to discharge the state of the responsibility of obligatory farm procurement and to enliven the market levers, the authority introduced a contractual purchase system in 1985. Contracts are established between the government and the peasants for the purchasing of part of 1984's production level and multiple price system was replaced with a single price at the average procurement price of the prior year. 
Under the new situations the peasants have to sustain pressures from both ensuring themselves the sale of their surplus on the one hand, and on the other hand, the rising of productive cost and shortage of productive materials which come with the generalization of the responsibility system' in all economic sector. The reduced investment in the early stage of the reform and the decontrolling of prices which followed have rendered many farm implements, such as seeds, fertilizer, machineries, and plastic membranes very expensive ${ }^{3}$ or even in dire shortage. The "double track" economic system and the often liberal interpretation of the contract terms enables cadres and officals to illegal profits and further complicate the position of the peasants. Furthermore, without a powerful local organizations most of the important public investments such as water conservation and irrigation started to deteriorate.

The growth of output value of farm production started to slowdown, from 7.2 percent in 1978-84 to 3 and 3.5. \% in 1985 and 1986. And the production costs continue to rise. The sown areas for grain has been reduced and the peasants turn to the production of much more lucrative activities. The shortage of foodgrain was soon felt. The government had to start again to import large amount of grain after 1985. And with the rise of prices of animal feeds, the scanty supply of certain food forced the government to reinstall the system of ration in some cities in 1987. Although rural workshops and small factories were also similarly affected, the processing of agricultural products or rudimental extract industries remained the most important alternative income powers for the rural population. In 1987 the non-farm output value bypassed the farm output value in China's rural areas for the first time. Nevertheless, large numbers of rural surplus population flow to the urban areas in seeking of a better living. It is estimated that by early 1989 there were some 50 millions of them. 
Between 1979 and 1984 during the first stage of reform in industrial and urban sector the measures adopted tends to simplify planning, and by authorizing enterprises to sell freely products above the plan target. Enterprises were allowed to retain profits from such selling. This proved to have little effect on overall economic growth (see Table ). In October 1984 the Central Committee decided to press on with the process. The scope of "imperative planning" has been drastically cut down, the profit delivery was replaced by tax payment, and greater management power was to be delegated to the directors. Together with the gradual reform since 1979 the number of products covered by compulsive planning was reduced from 120 to 60 and the number of materials under state unified planning diminished from 256 to $26^{4}$.

These measures cannot force enterprises to reduce their costs, to reinvest, or to prevent them from go for quick profits or to avoid taxes. Indeed, most of the profits has been distributed among the workers as bonus, making collective purchasing of consummer goods and construction of housing, or simply spent by cadres in banquets and trips. It encouraged the production of consummer goods which renders quick return of investment and fetches high prices in the market. The growth in industrial sector since 1984 is indeed very impressive. A Table shows, the speed of annual growth of total value of industry production between 1984-1988 is 2.77 times that of the first stage of reform. However, the major part of the growth come from industries of processing of consumer goods or those linked with them, while most of the basic industries are in difficult position. In order to keep a lid on inflation, the prices of basic industrial productions, such as oil and steel are still controlled by the government. Consequently those key industries often operate with loss and any further investment is detered. 
Little progress has been realized in other crucial domains in the reforms of industrial and urban sector. The effort to endow enterprise management with more autonomy has encountered strong resistance from the Party apparatus and can not be separated from the general political reform. Reform of employment system has created a large body of individual or private enterprises but remained helpless in changing the situation of "iron rice bowl" situation (where the workers are engaged for life and wage increases according to seniority) in collective or state owned enterprises. And without an open labour market, the government could not allow major enterprises to go bankrupt. Thus the situation where "the job of three persons is done by five people", and the continuous subsidizing of unproductive enterprises remain unchanged. This impedes replacement of outdated enterprises by more efficient ones.

From the beginning the Chinese Communists have always favored the urban population. This policy has been maintained after the reform. The rise in agricultural prices is cushioned by government subsidies to urban workers ${ }^{5}$, while the rise in production cost of industrial sector is shouldered by the key state enterprises. The food, cloth, coal, even soap supply for the urban areas are all subsidized by the government. Large scale unemployment is prevented by keeping surplus urban labour forces in urban enterprises, keeping productivity and labour utilization low. At the same time the rural areas keep the supply of cheap labour force for the service sectors and urban constructions.

The same consideration hinders the reform in urban land and construction uses. Housing has always been heavily subsidized by the government. The low average wages reinforced resistance to more realistic rental charges while decentralized economic power enables massive investment in 
construction. Construction ranks next to processing industry as the sectors receiving the most investment since the lauching of the reform. It is estimated that between 1979 and 1987 more than 1,644.1 billion yuan, about three times the state budget of 1987 , has been spent on it. The governmental subsidies for differences between procurement and urban rationed prices increased 5.8. times, while the state revenue increased only 34 percent between 1978 and 1984. The urban subsidies exceeded the amount of 50 billion yuan in $1987^{\circ}$.

\section{Problems Arising from Reform}

In striving for 'modernization' China has to confront several inherent difficulties : a very big and growing population, relative poor per capita natural resources, communication and transportation bottlenecks. Nevertheless, the situation is further complicated with problems resulting from these ten years reform. These can be summed up in three major inter-related issues : the 'overheated' and disequilibrium economic growth, inflation, and social disorder.

Between 1978 and 1988 China has achieved one of the most rapid economic growth ever registered. According to the estimations of the World Bank, for the period 1980-1985 China's $9.8 \%$ growth in GNP, the fastest among all the countries studied, far outstriped the $2.6 \%$ world average ${ }^{7}$. Chinese economic growth after 1985 is some 80 percent faster than in that period. Several factors of this "overheated" economic growth, as qualified by the Chinese, arouse serious concern.

First, a suitable growth ratio should be established between agriculture and industry. The total agricultural output value has been very rapid during the first stage of reform, according the Table, it was about 4.5. times that of 1952-1978. However, during the second stage the growth of agricultural sector has 
become negative while, at the same time, the growth of industrial production (including rural industries) was three times faster than before 1984. The burden of this overrapid industrial growth was borne by agriculture. The stagnation of the agricultural sector shows that it is not benefiting from the progress made in the industrial sector. At the same time the contradictory developments of the two sectors accentuates the existing clift between the urban and rural societies. On top of that with the drop in large proportion of marketable surplus, large amounts of food grain have to be imported for the expanding non-agricultural population and the deregulated population growth in the poorer areas.

A major factor in the decline of agricultural output value is the rapid decrease of state and local investment. One of the reform project was to increase investment in agriculture from the level of 11.1 percent of state investment in 1979 to 18 percent by 1985 . However, it was the contrary which had happened, that proportion steadily decreased. It was 5 percent in 1984 and 3.9 percent in $1985^{8}$. Furthermore, under the old collective system a certain amount used to be deducted from the production for capital construction and preservation, and the members could be drafted for that purpose. With the 'responsibility system' such local funds and mobilization have become extremely difficult or non-existant. After the first years of negligence China's very precarious irrigation and water conservation started to become seriously deteriorated. The same phenomena exists in soil fertility, forest and grassland preservation and all other local public works from road maintenance to health and welfare system. The sectors of education and 'planned birth' have also suffered from decreasing funds. These sectors are also affected by the craze of 'seeking profits' where young children are productive. 
The disequilibrium development of Chinese industrial growth sharpens the shortage of supply of some raw materials and intersectorial balance. The rapid increase of rural processing industries has diverted the raw material available to supply more efficient and productive modern factories, and forcing them to import or to work below their full capacity. Low investment in basic industries that requires long periods of gestation and pay off and lumpy social overhead capital has created shortage of some basic productive materials and energy supply.

Power shortage is a serious situation after 1985. It reached the point where factories in several major cities such as Shanghai could only operate three days a week by $1989^{9}$. And much of the industrial production can only be assured with importation of raw materials. For instance, by April 1989, it is estimated that 30-40 percent of China's consumption of rolled steel comes from abroad. Its reliance of imports of zinc and rubber is even higher, and a large part of its demand for the raw materials of chemical fibre has to be imported. Thus, the higher the speed of industrial growth, the more the country has to import, and the more severe becomes the shortage of foreign exchange ${ }^{10}$. The diversion from state revenue to enterprises investment or expenditure, import of production materials as well as consumer goods, and agricultural prices and urban subsidies resulted in state deficits. Officially, between 1979 and 1988 , with the exception of 1985 , the government ran a deficit now standing at 65 billion yuan (5.6 percent of national income in 1988) ${ }^{11}$.

China's retail price index has risen annually since 1985 . It culminated in 1988 with a figure of 18.5 percent higher than $1987^{12}$. In 32 large cities, the rate was even higher : 28 percent, as reported by the government ${ }^{13}$. With the deregulation of prices for certain goods, China's covert inflation emerged into 
the open. Several factors contributed to the persistence of inflation since the economic restructuring. The most important is the overheating which is translated into a serious inflationary pressure.

An imbalance existed between the relations of social production and accumulation on the one hand and consumption on the other. In 1988 the national accumulation rate was raised to 37.4 percent of national income (it was 24.2 percent between 1953 and 1957). One of the cause is the persistent high investment in fixed assets : 29 percent more than the budget in 1988. The demands, especially for consumer goods has far outstriped that of supply. To meet the social demands and excessive granting of loans, Chinese banks turned to the over-issuance of currency. Since 1979, China's money supply has grown at an average annual rate of more than 20 percent, while the GNP has been climbing at an average of just 9.4 percent ${ }^{14}$. The over-issuance of money amounted to 67.96 billion yuan in 1988 raising the amount of money in circulation by 46.7 percent between the end of 1987 and 1988. By the end of 1988, it is estimated that surplus public purchasing power had topped 560 billion yuan ${ }^{15}$.

By far the most important problem arising from the ten years of reform is the degeneration of social order. A multitude of social problems occurred with the yielding of political control in the rural grassroot level and encouraging of 'getting rich' as the paramont social moral have all been eclipsed by corruption and abuse of power of government officials and party cadres.

The 'household responsibility' system favoring those with more ablebodied labour created visible differentiation between families in the same village. The appearance of 'specialized households' brings into being the real profound cleavage between the rich and the poor in the countryside. Likewise, the 
emergence of large and profitable private enterprises in the urban areas created a special class of new rich. Under the general corrupted social ethics, people could use their wealth to 'purchase' the right to have an extra child, to influence officials and even to buy points for the studies of their children. Often with little education and unable to find a outlet for their capital under the 'primary stage' socialism economic system, many used their profit to lead an ostentatious life. They often became the targets of envy and criticism, while the social differentiation brought on increasing occurrences of crimes of all kinds.

However, the problem with the most profound social implications is the rampant bureaucratic corruption. That corruption is prevalent in the Chinese Communist Party is a well-known fact. Since the reform was initiated, the situation has deteriorated very much. As in most societies during the transitional process of modernization, corruption involves an exchange of political action for economic gain. In the case of China, the omnipresence of the party structure and the impass of separation of economic management from political power have enabled the officials and party cadres to make use of their posts for private gain. With the decentralized economic power and the direct control of capital by the functionaries, the extravagance, waste, and issuing bonuses and materials at the expense of the country's interest have reached an unprecedented scale. Rampant power abuse and dereliction of duties in Mainland China has been used for economic gains with the "commerce craze" after 1984. The most common forms are graft and bribery. According to official statistics reported in early 1989, among those grafters who are claimed for crimes, nearly 53 percent are government functionaries. Of those who have been sentenced, about 74 percent are government employees ${ }^{16}$. 
The bureaucratic profiteering has the most far-reaching effect on the national economy and fundamental legitimacy of the regime. Commercial agencies have been established not only by Party and government organs in charge of economic affairs, but also by judicial and legislative departments. With their authority over finance, resources distribution, production quotas, and commodity prices, they found it very easy to make money. One report claims that at the end of 1987, about 250,000 out of total 360,000 such companies in China were engaged in reselling materials and goods allotted by the state ${ }^{17}$. In the second half of 1988 a crime-reporting system established by the government in a special effort to crack down on them, registered complains about criminal actions by more than 24,000 party and government officials, including 17 ministerial and provincial levels ${ }^{18}$. Even if the officials are not personally involved in corruption many of their relatives and descendents of top leaders are implicated in such cases. The bureaucratic corruption not only created direct loss to the national economy, as a major economic link, the illegal reselling of materials and products is considered to be one of the most important factors in driving the prices up.

The situation is deeply resented by the people. Several surveys had been conducted on the subject. 62 percent of the respondents of one of these surveys conducted over some three thousand people in Mainland China replied that they are not satisfied with the Chinese Communist Party, the highest rates of unsatisfaction are among the intellectuals, 70 percent, and followed by cadres 69 percent $^{19}$. In August the Institute of Sociology of the Chinese Academy of Social Sciences and the State Statistical Bureau conducted a large poll in 16 cities where close to 10,000 workers responded. Some 61 percent put the blame for the rise in lawlessness in the propensity of government officials to take advantage of their position to break the law. And a mere 24 percent of the respondents 
believed that more people today than in the past wanted to join the party, while 35 percent felt the reverse ${ }^{20}$.

There are indications that common anger against corruption of the bureaucrats has overshadowed differences among the people. More and more crimes are organized to take advantage from the state's. For example, 1,800 train robberies have been reported in the first quater of 1989, an 89 percent increase over the same period of 1988. Most of them involve a large number of people, including cadres, railway workers and security personnel. An interesting case is reported by Outlook magazine. It said that except a disabled old woman, everybody in a small village on the Guiyang-Kunming railline hag been engaged in over 40 cases of freight robbery. They not only receive perfect cooperation from the railway workers, but also have a ethic system which covers every member and their families ${ }^{21}$.

\section{Inherent Limitations of Reform}

After 1978, the new leadership has been determined to improve the living standard of its people and in making China a full fledged member of a modernized world. Moreover, they have realized that the very survival of the regime depends upon the successes in these domains. However, the unwillingness and inability to modify some of the fundamental elements within the political and economic system in the Chinese Mainland has more or less proscribed the modernizing efforts.

Except for short periods in the history of Chinese Communist, the Party has often embarked upon various schemes with subjective volontarism as the main instrument, without proper previous study of feasibility. Such tendancy exists from the purchase of a specific foreign factory to the launching of such grandiose movement as the 'Great leap Forward'. The economic reform is another unfortunate 
example of such propensity. The absence of any overall plan or program can be detected clearly even from our brief account of its evolution. Admittedly, to modernize a country with an enormous population of low educational level, a diversed geographic configuration, relative poor per capita natural resources, and with an ossified unbalanced economic system is certainly a very difficult undertaking. However, rather than pulling all the talents and knowlege available for the task, the Chinese government has adopted a non-scientific and opaque approach. The expression often used by Chinese leaders in describing the manner in which their reform process advances is "crossing river by groping stones".

For example, agricultural production needs timely inputs of market informations, funds for seeds, fertilizer, water, harvest as well as processing machineries, and transportation facilities. These needs are all the more acute when the productivity is increasing and when the economic units are reduced to small households from rural collectives. Not only the industrial sectors are not mobilized to meet these needs, or the bottlenecks of infrastructure improved, no form of farmer association or service system are set up to replace the roles played by the collective authorities. The results is that the profit margin of agricultural production became so low that rather than going through the endless trouble of meeting all these conditions, and pay tax or contract responsibilities, many rural people are obliged to abandon their alloted plots. The grain sowing areas has been reduced 22 and the output value of agricultural production declined. The economic system is not really regarded as a dynamic whole but rather as separate issues to be tackled in the order of facility.

In decentralizing economic power without establishing an effective alternative system, the government has lost macroeconomic control. After a period of uncertainty and 
hesitation, the power of most international commercial economic interactions had been relegated to provincial governments. Furthermore, the opening of 'special economic zones' steadily expanded to include most of the coastal areas. The Chinese government gradually loses command over the types and level of technological importation, the kinds of industries and terms of foreign involvement on its soil. Moreover, there are no mechanism to prevent cut rate competition between different administrative regions or the backflow of goods originally exported from other areas.

The replacement of the part of the economy moved from under 'compulsory plans' to market economy was to be accompanied by tax and credit mechanism. However, no accounting or tax system has been properly worked out. The newly promulgated laws are not only full of flaws but also disrespected. For decades Chinese had been reminded of the bitter days when land rent and tax existed. The resentment of tax collector is especially strong in the rural areas. Especially, when after 1985 more and more rural local governments found it difficult to meet their part of the contract, unable to deliver the fertilizer, diesel oil or seed grain as promised in the contract or having to give 'tiaozi' (strips of paper of I.O.U.) rather than cash for procurement. The task of tax collecting in the rural areas has become a very dangerous matter. The interwinding relations of political power and enterprises created numerous lopholes for tax evasions. The state revenue is deeply affected by the situation and taxation proved of no use in macroeconomic control.

Banks failed to be an effective economic leverage. The decentralization made it possible for banks, like the rest of the society, to favor occasions that could bring in quick and large economic returns. Enterprises are allowed to pay back loans before turning in profits or tax, which encouraged social 
spending such as construction. Furthermore, the lower interest rate and high inflation rate discouraged saving and thus the amount of bank credits. At the same time, without alternative producing sources, welfare or free labour market, the government could not afford to let large enterprises go bankrupcy which have to be subsidized with loans.

The most important factor which impedes the proper functioning of regulations, laws and market mechanism is the fusion of political power and gains. The importance and basic principles for the separation of party and government, the party and economy management has been spelled out by Deng Xiaoping as early as August $1980^{24}$ and a project (the Gengshen Reform Programme) has been worket out. However, real reform in this domain has been effectively blocked by the inviolability of the cardinal principles of : leadership of Communist Party, people's democracy, the socialist road, and the Marxism-Leninism and the Thought of Mao Zedong. Other than the streamlining of bureaucratic structure, very little could have been achieved in this sphere. Attempting to put political reform back on the programm, the Party encouraged the discussion on the matter in 1986. The intellectuals' world started to engage in really heated debate on democracy, the separation of legislative, administrative and judiciary powers as well as freedom of opinion. The debate found its echo among the students. This was far beyond what the old revolutionary guards, who holds the real power in China's political scene could tolerate. The incidents resulted in the dismissal of $\mathrm{Hu}$ Yaobang as the Party Secretary, the purge of some liberals and the further retrenchment of the Party.

As long as the party committee or its secretary holds the real power in the government and enterprises the ills of the reform could not be solved. There is no way to reinforce economic leverages such as tax, accounting and credits, or to stop 
rampant bureaucratic profiteering, corruption, and nepotism. The government would have little funds to invest in desperately needed social overheads such as infrastructure, education, water conservation, or basic industries. By 1988 Chinese Communists have become fully conscious of the need for reajustments in economic field, but the measures taken aimed at maximizing the party authority.

\section{Retrenchment}

Various attempts to curb economic problems through price and wage readjustments, bank and financial regulations and tightening of disciplinary measures have all failed to bring about real improvements. In September 1988, during the third Plenum of the 13th Central Committee of the Chinese Communist Party the new policy of "improving the economic environment and stabilizing the economic order" during the next two years has been announced by the Party Secretary Zhao Ziyang. He was quite explicit in insisting that the double-track (planned and market) pricing system for certain products and materials would be maintained. And the communique issued at the end of the Plenum noted that China's general economic situation remained sound, but conceded that difficulties had emerged out of recent reforms.

Throughout 1988 heated debates had been held during meetings initiated among independent scholars, symposiums sponsored by the Party, or in journalistic and academic publications over the best ways to deal with socio-economic ills. While most agree upon the need for foreign participation and economic development they differ very much as to the best approach of economic reform in China. The different views are reflected in the inner party discussions such as during the fourth Meeting of the seventh NPC Standing Committee held from 31 October to 8 November 1988. 
During the meeting some delegates articulated misgivings which a number of people had voiced. They urged the mass media to provide effective supervision of efforts to improve the domestic economy. There was criticism of disorderly economic conduct and government corruption, which was thought to have threatened the gains of the last decade, and demands for more stringent measures to improve the currently-inadequate implementation of laws and regulations ${ }^{25}$. Some other members used the arguments of the emerging theory of 'new authoritarianism'. The advocates of this theory claims the success of the New Industrialized Countries are due to strong authorities enjoyed by the leaders of these regimes during the developing stages. Furthermore, this theory panders to the sentiments of the party hardliners who had not been pleased with the "liberal" tendance of the reform. Thus, there were calls to give greater powers to the central authorities in order to enforce the bans and prohibitions that were needed to check price rises and other inflationary pressures ${ }^{26}$.

Under the policy of 'improvement and stabilization' the three immediate major task are : major reduction in fixed investment and strict control of consumption funds; the formation of clear industrial policy; and comprehensive reforms (aiming at slowing down price reform, but accelerating enterprise reform and improvement in macro-economic control). Zhao Ziyang saw the readjustment of China's economic structure, including the complete separation of political power and economic enterprises ${ }^{25}$, as the key to the policy. As for Li Peng, the new Prime Minister of the State Council, noted in the end of November 1988, that if economic methods proved ineffective as means of fulfilling desired objectives, then 'administrative' (a euphemism for high handed political pressure) methods - "including some effective means which we used in the past" - would be adopted ${ }^{26}$. 
Policy and measures of 'improvement and stabilization' have had little effects. As a popular saying goes, "the lower levels have counter-measures for whatever policy taken by the higher authority". The investment in capital construction in 1988 was still 20 percent higher than 1987. Many of the suspended projects had been created for just such occasions, and some scraped projects are essential to the economic development. Consumption funds have continued to expand. In February 1989, they stood at 20 billion yuan more than 12 months earlier. Tax evasion is practised by an estimated 70 percent of industrial and commercial enterprises. Since the stipulation on taxation of collective banquet expenses, between September 1988 and March 1989, the state has only collected 470,000 yuan --- about the tax payment of a medium restaurant for one year ${ }^{29}$. And with the combined effects of price adjustment, over issuance of currency and decreased industrial growth the inflation rate would not be able to be controlled within 10 percent in 1989 as planned ${ }^{30}$. The disequilibrium between industrial and agricultural sectors increased from the difference of three folds in 1987 to 7 folds in 1988.

By 1989, there were increasing evidences that Zhao Ziyang had been relieved of responsibility in economic work, and the advocates of 'new authoritarianism' were gaining upper hands as the solution to China's problems. In his report to the Second Session of National People's Congress held in April 1989, Li Peng openly recognized that mistakes had been committed in economic reform. This was a direct criticism to policies and measures decided under the leadership of Zhao Ziyang. Policies for further reform previously announced such as : reforms of housing and market system; joint-stock, stock market, bankrupcy and merger in enterprises reform, as well as the changing of personnel and participation of more non-partisans 
in the government had all been suspended. The economic reform had effectively came to a halt. The emphasis was to "conpress social demands without vacilation".

At the same time, politically, the party has repeatedly stressed the need of 'stability and unity'. Fearful of social instability for the seventieth anniversary of the first student movement on the Fourth of May and other major occasions in 1989, the government started to give instructions concerning the content and tones of all public pronouncement and media publication at the end of $1988^{31}$. Such tight control of political expression without waging of political campaign, such as 'spiritual pollution' or 'bourgeois liberalism' is unprecedented since 1978. It seems that, unable to retract the decentralized economic powers to remedy socio-economic problems after the ten years of reform, the Chinese leaders are trying to regain their power through the reinforcement of authority.

\section{Conclusion}

Ten years of economic reform has brought 'growth' to China, although an unbalanced and disequilibrius one. An average annual growth of 14.4 percent of national income for ten years is indeed a remarkable achievement for a country with so many people to feed and such a vast territory to govern. Nevertheless, the result is a far cry from the real 'development' that China was seeking. David E. Apter has defined development as the "structuralization of political-socioeconomic activities" which has the characteristics of systemization, rationalization, legalization, specialization, planification ${ }^{32}$. The reform of China has missed all these attributions. It is not surprising that such 'growth' arouses many problems and could not be maintained. 
The agricultural sector is the first to have gone through the cycle of rapid growth and decline. Its growth up to 1984 had been acquired through a rationalization of land and human resources utilization. Once the pent up productivities had been released and the reserve of the last 30 years (especially in capital construction) had been exhausted the downswing became inevitable. The sector needs enourmous amount of investment and reorganization to stop the continuous decline. To a large measure, the brisk growth of industrial output since 1985 has benefited from funds diverted from agricultural sector through unbalanced price and investment system as well as from national and international credits. Furthermore, its growth comes from the sacrifice of productivity. Compared with 1979, the proportion of non-rural industrial output value in total national production decreased 1.3 percent, while at the same time the proportion of all employment increased 4.6 percent. And the margin of investment-productivity benefit has also declined, it dropped 15 percent in one single year of $1986^{33}$.

This ten years' reform has added more problems to the already precarious state of China's economy. It is probably more difficult to attain the goal of 'modernization' even if China is to embark on a more rational path now than it was in the last ten years. Less than 20 percent of China's high investment in the last ten years has gone on developing energy, transport, communications and important raw material resources ${ }^{34}$. The meager growth of these basic industries and infrastructure sets the limit to future development. By neglecting these sectors China would have great difficulties in absorbing the large army of young people who would come into the labour market and the surplus workforce of the rural area. The development of human resources is also more than disappointing. Education has been so neglected that even Deng Xiaoping admitted that is the biggest mistake of the reform ${ }^{35}$. The population growth which was to be contained by the policy 
of 'one child per couple' has become out of the governmental control after the stringent campaign of 1983-84. However, more than the growth, the underegistration or the disobedience of the people, it is the sign of discredit of the 'planned birth' propaganda and methods such as 'reward and sanction' in the eyes of both the cadres and the people which is more significant in the socio-political environment of China.

Another factor that would make China's modernization effort even more difficult is the worsening environmental situation. Such problems as the shrinking of forest and water surface, soil erosion, and the expansion of desert and salined land have already increased the frequency of natural disasters, the shortage of water and arable land. Ten years of high and random consumption growth increased the speed of deterioration. Uncontrolled extraction of natural resources by a multitude of small workshops and village industries has done great damage to many mineral deposit. The great majority of them have so little capital that they could not afford installations against pollution and further deteriorated China's natural environment. Factories and housing constructions have taken up precious arable land. They have also added to the problem of pollution.

However, at least one element in the reform will bring and has brought profound changes to the mentality of the Chinese people, that is the opening to the outside world. Contact with the advanced countries bring with it the realization of the backwardness of China and the urgency of catching up. Knowledge of countries which managed to 'development' in a large sense has also deeply shocked the Chinese into action. Some tens of thousands of students and scholars have visited or studied in other countries. This has opened widely the sight of some of the most brilliant people who had been confined in 
China's powerful propaganda machineries. The benefits of an open society has convinced many people.

Chinese people have put forward the demand for democracy, freedom of the press, and scientific approach because only with all the right elements can societies be 'able to choose a direction and means of change ${ }^{136}$ in the process of development. It has always been one person or a little group of people who dictated 'the best and the only way' for China. And it has been proven that mistakes have been committed repeatedly. Ten years after the economic reform the economic ills are profound, the Chinese people confront economic difficulties everyday in the form of inflation, in self-fulfillment as in education, in the future in the form of employment and opportunites. During the whole movement of 'democracy' in spring 1989, neither the student nor the workers or ordinary citizens expressed complaints only about the economy. Beyond the noble appeal of 'freedom' and 'democracy' may be they are also aware of that 'choice' implies rationality and that debate and informations are caracteristics and prerequisites of modernity. 


\section{NOTES AND REFERENCES}

1. For example the grain procurement price has been raised $20 \%$, and that of deliveries in excess of procurement quota $50 \%$ in 1979.

2. The output value of non-grain farm activities increased $63 \%$ between 1980 and 1984--an average of $13 \%$ per annum, compared with that of grain productions which was $6.4 \%$ per annum. Zhongguo Nongyue Nianjian 1986, (Yearbook of Chinese Agriculture), Beijing, Zhongguo Tongji Ju Chuban She, 1987, pp. 166-167.

3. According to the State Statistic Bureau, compared with 1983 the 1985 prices of fertilizer went up $43 \%$, that of every horsepower of rural mechanization $92.1 \%$, and that of agricultural pesticide $82.6 \%$ Xinhua Wenzhai (Xinhua Digest), $n^{\circ} 8,1988$, p. 111.

4. "The Chinese Economy in 1988", Beijing Review, February 6-12, 1989, p. 21.

5. Such subsidies reached the height of 37 billion yuan, or about a quarter of central government expenditure in 1984. D. Gale Johnson, "Economic Reforms in the Pcople's Republic of China", Economic Development and Cultural Change, Vol. 36, $\mathrm{n}^{\circ} 3$, Supplement April 1988, p. 232.

6. Liu Yuanda and He Xiaolin, "Cong Wujia Kan Guoing", (Analysis of National Conditions from Prices), Renmin Ribao, (People's Daily), June 22, 1988.

7. Banque Mondiale, Rapport sur le développement dans le monde 1987, Washington D.C., 1987.

8. Xinhua Wenzhai, op.cit.

9. "Power Shortage Threatens China", Beijing Review, Feb. 27-March 5,1989, p. 7.

10. Wang Jiye, "The State, the Market and the Enterprise", Beijing Review, April 10-16, 1989, p. 18. 
11. Li Rongxia, "From the NPC and CPPCC : The Need for Macroeconomic Regulation", Beijing Review, April 17-23, 1989, p. 21. It is admitted that the deficits announced by the Chinese government are only a part of the real deficits.

12. Dai Yannian, "Can Inflation be Curbed ?", Beijing Review, February 13-26, 1989, p. 4.

13. Wang Jiye, "The State, the Market and the Enterprise", Beijing Review, April 10-16, 1989, p. 18. Those figures are strongly challenged by reports from Hong Kong, many claims that the rise of retail prices of daily commodities from food to cloth to houschold elecricity products ranges from 50 percent to two times. See for example Zheng-Min, May 1989, p. 54-55.

14. Dai Yannian, op.cit.

15. Li Rongxia, op.cit., p. 22 and 21.

16. "Government's Workstyle", Liaowang, (Outlook Weekly), Issue $\mathrm{n}^{\circ}$ $47,1988$.

17. Ming Bao, (Ming Daily) Hong Kong, August 1, 1988, p. 9.

18. Beijing Review, Jan. 30-Feb. 5, 1989, p. 9.

19. Zheng Ming, (Contant), Hong Kong, $\mathrm{n}^{\circ} 139$, May 1989, p. 51.

20. Ellen Salem, "Still Mired in Muck", Far Eastern Economic Review, 2 March 1989, p. 63.

21. "Train Robberies Harass Travel", Beijing Review, $\mathrm{n}^{\circ}$ 19, May 8-14, 1989, pp. 4-7.

22. It diminished some $5.1 \%$ between 1980 and 1985. Zhongguo Nongye Nianjian, (China Agricultural Yearbook), 1988. 
23. A report from Hong Kong says that between 1985 and the first half of $1988,6,420$ tax collectors had been beaten, with 13 dead and more than 800 heavily wounded. Guangjiaojin Yuekan, (Wideangle Monthly), April 1989, p. 40.

24. "The Reform of the Leadership Institution of the Party and the State", Selected Works of Deng Xiaoping, (Beijing : Renmin Chubanshe, 1983), pp. 280-302.

25. Summary of World Broadcasts, Part 3 : The Far East FE/0300 and 0301.

26. Summary of World Broadcasts, Part 3 : The Far East FE/0303.

27. He explicitely expressed that view in Shenzhen in March 1989. Jingbao, (The Mirror), Hong Kong, April 1989, p. 36.

28. Summary of World Broadcasts, Part 3 : The Far East FE/0323,0327 and 0329.

29. Li Rongxia, op.cit., p. 21-22.

30. Ron Zhang, Jingbao (The Mirror), Hong Kong, April 1989, p. 24.

31. Guang Jiao Jin, (Wide Angle), Hong Kong, April 16, 1989, p. 10-18; ling Bao (The Mirror), Hong Kong, April 1989, p. 18-27.

32. David E. Apter, The Politics of Modernization, (Chicago and London : The University of Chicago Press, 1965).

33. Jingji Ribao, (Economic Daily), Beijing, November 11, 1988.

34. Li Ning, "Curbing Capital Construction", Beijing Review, February 6-12, 1989, p. 21.

35. See also reports on Guangmin Ribao, (Brilliant Daily), Beijing, June $9,10,11,1988$.

36. Apter, op.cit. 


\section{RESUME}

Sous la direction de Deng Xiaoping, la Chine a entamé la réforme économique la plus audacieuse jamais lancée dans un régime communiste auparavant. Entre 1978 et 1988, le revenu national de la Chine a augmenté avec une vitesse annuelle de $14 \%$, plus de deux fois plus importante que celle enregistrée entre 1952 et 1978, et bien plus vite que la moyenne de $3 \%$ de croissance mondiale. La croissance est enregistrée aussi bien dans le secteur de la production agraire que dans ceux des industries légère et lourde. Mais cet article vise à démontrer que cette croissance économique a apporté beaucoup de problèmes et que, en réalité, dix ans après le lancement de cette réforme, le vrai 'développement' de la Chine sera bien plus difficile qu'avant.

Ce phénomène est fortement lié à l'évolution menée de la réforme, dans laquelle le premier stade est caractérisé par l'abandon de l'intention originale et son remplacement par le développement spontané dans la campagne du système de la 'responsabilité' par foyer ou individuel et par la propulsion de cette formule dans la zone urbaine et dans le secteur de l'industrie. Dans ce processus, la 'libéralisation' est devenue synonyme de 'profit' et elle dépouille la réforme de ce qu'elle contenait en fait de programme. Très vite, de nombreux problèmes ont surgi comme la surchauffe et le déséquilibre des économies, l'inflation et des désordres sociaux.

Le manque d'un plan global démontre la caractéristique du volontarisme qui représente une des limitations inhérentes au parti communiste chinois. La décentralisation non-coordonnée et, à défaut, l'utilisation de mécanismes qui remplacent les contraintes précédentes de l'économie centralisée, ont eu 
comme résultat la perte du contrôle central de la macroéconomie. L'impasse dans le domaine de la réforme politique a bloqué l'exécution effective des nouvelles dispositions économiques et a créé des désordres socio-politiques.

Vers 1988, le débat au sein des instances centrales du parti pour résoudre les difficultés économiques s'est déroulé suivant deux lignes : la première préconise de pousser plus loin la réforme, ce qui implique la nécessité d'une réforme politique; la deuxième appuie l'assainissement qui restitue la plupart des contrôles politiques au parti communiste comme avant la réforme. En 1989, le triomphe de ceux qui prônent l'assainissement devient évident.

Le manque de "caractéristiques de systématisation, rationalisation, légalisation, spécialisation et planification dans la structuration des activités politico-socio-économies", la définition donnée par David E. Apter pour le 'développement', pendant ces dix années de réforme et de croissance économique chinoises est frappant. Les problèmes de goulots d'étranglements existants dans les industries de base, l'infrastructure et l'irrigation, le développement des matières premières, ainsi que le développement des ressources humaines, et la politique de planification des naissances ont tous subi encore des régressions très importantes. De plus, la situation déjà alarmante de l'environnement et de la pollution s'est énormément aggravée avec la croissance économique.

Mais l'ouverture vers le monde extérieur et les dizaines de milliers d'étudiants et de professionnels qui ont effectué des séjours à l'étranger ont apporté des changements profonds dans la mentalité de beaucoup de Chinois. C'est notre souhait que derrière les nobles demandes de liberté et de démocratie 
pendant le mouvement de 'démocratisation' du printemps 1989, existe aussi la prise de conscience que des débats et une information libres sont des conditions préalables $\mathrm{du}$ développement. 